\title{
DROUGHT RISK AND ITS PERCEPTION BY FARMERS
}

\author{
Monika Kaczala ${ }^{1}$
}

DOI: https://doi.org/10.31410/ERAZ.S.P.2019.69

\begin{abstract}
The purpose of this research is to investigate the cognitive perception of risk among Polish farmers and the factors which have an impact on this perception. Statistical analysis and logit models were applied for analysing the representative poll taken in February and March 2019 in Poland (N=200). Farmers' risk perception is dominated by the subjective factors (average loss caused by drought in the previous year, frequency of other types of impact of drought, catastrophic potential of drought risk, immediacy of effect, the degree to which the risk is known to science, number of farms susceptible to drought, trust in experts' assessment of drought, trust in the media informing about drought, age and level of education) to a much higher extent than by the objective ones (monthly income, specialising in plant output, high-cost crops, the share of income from farming in the whole income).
\end{abstract}

Keywords: Drought, risk perception, Poland, agriculture.

\section{INTRODUCTION}

$\mathrm{W}$ ater scarcity is one of the key issues in the area of food security [1] and it is caused, inter alia, by exacerbation of extreme phenomena such as drought [2]. In Europe between 1982-2012 the number and impact of droughts increased dramatically [3]. In the past two years alone there have been two severe droughts in this area - 2017 in the south on the Iberian Peninsula and in Italy [4,5], while in 2018 in most countries of the northern and central Europe [6].

Soil drought affects the financial situation of the farm, and in extreme cases may lead to its bankruptcy [7]. The farms concerned are the ones based either on plant or animal output. Dramatic situation of livestock farmers in Denmark can be a prime example of such problems, along with significant difficulties of Polish plant farms affected by drought, where in certain cases loss in some regions reached over $70 \%$ of the crop's value.

Soil drought is a systemic risk and therefore its management is essentially a task within the realm of the state [7]. The EU member states are obliged to implement action with regard to drought impact prevention, which is derived directly from (OJ L 327, 22.12,200, p. 1). Moreover, Common Agricultural Policy places particular emphasis on the issues related to risk management in agriculture. Regardless of embracing the concept of the so-called risk governance the most crucial issue which is decisive for the whole process is recognition and investigation into the system stakeholders. The key group of stakeholders consists of farmers. Identification of the structure of perceived risk and the formation of farmers' risk perceptions seems to be crucial both for designing a governmental risk management policy applicable in the agricultural sector and for suppliers of risk management tools [8-10].

Farmers' perception of risk has been extensively researched, especially in the United States, Australia and developing countries [11-13] and also in Europe [14-16]. However, almost no research has been conducted so far to determine farmer's risk perception in the Eastern and Cen-

Department of Insurance, Poznań University of Economics and Business, Al. Niepodległości 10, 61-875

Poznań, Poland 
tral Europe (especially in the post-communist countries) [17], despite the fact that the perception of risk among farmers could vary depending on the country they operate in [18].

Bearing the above in mind, the purpose of this research is to investigate the perception of risk with respect to drought among Polish farmers. Poland as an example of a Central European post-communist country has been selected for this study, because it is one of the main suppliers of area and people in the EU agriculture (it accounts for $8 \%$ of the EU arable land and 19\% of the EU population economically active in agriculture) [19].

\section{LITERATURE REVIEW}

The literature points to a number of factors which affect the cognitive perception of risk. In accordance with the expected utility theory it is assumed that the subject possesses perfect information and established preferences, thus their risk perception is identical as the so-called objective risk. Objective risk, in turn, depends on factors affecting the level of likelihood of drought occurring in a particular area; these factors are identified in literature as affecting exposure to risk; in the other group of factors are the ones affecting the scope of damage - these factors are denoted as the ones which determine sensitivity or vulnerability to drought [20]. The level of exposure to risk depends primarily on the farm's location [21,22]. This variable however, in the analysed research is not very much diversified because the data refers to three voivodships located in vicinity of each other in central and north-western Poland. Nevertheless, the following hypothesis has been put forward:

H1_1: $\quad$ Perception of drought risk depends on the location of the farm.

The level of exposure to risk also depends on the value which is prone to reduction. It was assumed in the study that this is the average monthly income from farming reflecting the income from crops and animal production [16]. Therefore, another hypothesis was formed:

H1_2: The greater the average monthly income from farming is, the higher the perception of drought becomes.

Similarly, exposure to risk can be connected with the amount of arable land. Hence, the third hypothesis:

H1_3: The greater the amount of arable land in the farm, the higher the risk perception. The level of vulnerability to drought in agriculture can be affected by several factors $[23,24]$. In Poland the monitoring system is based on the climatic water balance [25], in which value limits denoting drought depend on the type of soil and type of cultivated crops. Hence the following hypotheses have been put forward:

H1_4: The higher the average soil class in the farm, the lower the perception of drought risk.

H1_5: Perception of drought risk is contingent on the type of cultivated plants (detailed hypotheses from H1_5_1 to H1_5_2, cf. Table 1).

Vulnerability to drought risk may also depend on the farms specialisation which affects the level of loss in plant output $[13,26]$. Hence the following research hypothesis:

H1_6: The farmers who specialise in plant cultivation perceive the risk of drought as higher than those who manage farms with other specialisations.

Vulnerability, i.e. the degree to which the farm responds to drought, might also be linked with the percentage of income from farming operations within the whole of the income [26]. Hence: 
H1_7: The greater the share of income from farming operations in the whole income of the farm, the higher the perception of risk.

Within the theory of risk perception a number of subjective factors is considered which determine risk perception [10]. D. Khanemann and A. Tversky within their prospect theory $[27,28]$ point to numerous heuristics affecting the evaluation of probability by individuals, including availability heuristic [29]. Therefore it was assumed that experiences are indispensable in order to evaluate probability - when and how often the loss caused by drought occurred as well as its scope [26,30-33]. It was also assumed that if within the prospect theory respondents are allowed to select various reference points, different types of loss may affect drought risk perception differently [27]. Therefore, the following hypotheses were put forward:

H1_8: The higher the average loss in farm's yield caused by drought in the previous year the higher the risk perception.

H1_9: The higher the average loss in farm's income caused by drought in the previous year the higher the risk perception.

H1_10: Influence of experience on drought risk perception depends on the frequency of occurrences of particular impact (Hypotheses from H1_10_1 to H1_10_19 cf. Table 1). Based on the psychometric paradigm [34-37] and its empirical verification [38-43] so far it was assumed that special influence on drought risk perception may be exerted by three elements. The first one, defined as „risk causing fear" consists of the level of fear caused by drought, risk controllability by the respondent and impact severity and catastrophic character. The second factor denoted in literature as ,unknown risk" consists of the following features: risk known to persons who are not exposed to it, risk known to science, barely visible implications, immediacy of effect. The third factor encompasses aspects like risk newness (familiarity) or the range of the impact scope (common exposure). With regard to the factors resulting from the psychometric paradigm the following hypotheses were formed:

H1_11: Drought risk perception depends on perceptions of particular aspects of this risk by the respondent (detailed hypotheses H1_11_1 to H1_11_12 are presented in table 1).

Considering the sociological and cultural risk theory and the empirical research to date, it has to be said that risk perception can also be affected by vulnerability to group impact and the level of trust in external institutions which deal with drought risk management $[33,44]$. Assuming that group influence can be measured by degree, to which other farmers' opinions are taken into consideration when making decisions about controlling drought risk, the following hypotheses were formed:

H1_12: The more important the farm manager finds the other farmers' opinion about the choice of tools for preventing the impact of drought, the higher the drought risk perception.

H1_13: The higher the level of trust of the farmer in institutions engaged in drought risk management system and the system itself the weaker the risk perception (detailed hypotheses H1_13_1 to H1_13_7 are presented in table 1).

H1_14: The higher the level of trust in the media informing about drought the lower the risk perception.

Moreover, it was assumed that certain sociodemographic features - age, gender and education - may affect drought risk perception although it must be stated that research findings so far are not unambiguous. However, it was assumed that:

H1_15: The older the farmer, the lower the drought risk perception.

H1_16: Women present a higher drought risk perception than men. 
H1_17_1: The higher the level of education, the lower the risk perception.

H1_17_2: Agricultural education lowers the level of drought risk perception.

Subsequently, a question was posed whether subjective factors explain risk perception to a greater extent than objective factors. In the course of seeking the answer to this query three regression models were estimated. The first one is based only on objective factors, the second one only on subjective factors, while the third on all the exogenous variables.

\section{MATERIAL AND METHODS}

The primary data was gathered on the basis of a survey conducted in February 2019 by means of direct interview, with the use of the structured questionnaire schedule, on a focus group of 200 farmers in three voivodships in Poland extremely exposed to drought. A representative sample was selected on the basis of the farm location and size.

Cognitive risk perceptions (RP) were measured by asking respondents about their perceived likelihood and perceived severity regarding drought. Measuring the perception of risk with the use of two variables, namely subjective probability of a damage-causing occurrence and the scope of the damage, is one of the more often quoted in studies [45-47]. The two variables are treated as essential when perception of risk is measured, and they can also be supplemented with other dimensions [zob. np. ,48]. The participants assess the subjective probability (SP) of drought in their farm using a percentage scale (with $0 \%=$ "impossible to happen," whereas $100 \%=$ "certain to happen"). The perceived severity was measured by asking about the severity of average consequences resulting from being exposed to drought with respect to crop (LC) and income (LI) using a percentage scale (with $0 \%=$ "no loss" whereas $100 \%=$ "total loss").

Therefore, it was assumed that:

$$
\mathrm{RP}=\mathrm{SP} \times((\mathrm{LC}+\mathrm{LI})) / 2 \div 100 \%
$$

$\mathrm{RP}$ - risk perception, in $\%$

$\mathrm{SP}$ - subjective probability of drought, in $\%$

LC - loss of crop due to drought, in $\%$

LI - loss of income due to drought, in \%

Distribution of RP variable is strongly asymmetric (on the right-hand side) and is characterised by a relatively high degree of concentration which makes it significantly different from the normal distribution.

In order to verify the hypotheses various statistical tests were conducted, the type of which was contingent upon the kinds of the studied variables. The choice was also made considering that the endogenous variable (RP) was a quantitative and constant one, but its distribution was characterised by high kurtosis, strong right-sided asymmetry and was significantly different from the normal distribution. Due to this, non-parametric test was favoured and the following were used: The Spearman's rank-order correlation coefficient, Kruskall-Wallis test and U-Mann-Whitney test.

To investigate the perception of drought three regression models were estimated. The goodness fit of the models has been measured by adjusted R2. The significance of the variables is 
estimated using a two-sided t-Student test. In all the cases the change of R2 that is achieved through expanding the set of variables with subjective factors is assessed by applying F-test corresponding p-values are presented (table 2).

\section{RESULTS}

The findings of the conducted analyses verifying hypotheses H1_1 to H1_17 are presented in Table 1, while table 2 presents research findings concerning evaluation of the degree to which risk perception is affected by subjective and objective factors.

Table 1. Factors affecting perception of drought risk - quantitative verification of hypotheses

\begin{tabular}{|c|c|c|c|c|c|}
\hline Variable & Hypothesis & $\begin{array}{l}\text { Kruskal- } \\
\text { Wallis } \\
\text { Test } \\
\text { (p-value) }\end{array}$ & $\begin{array}{c}\text { Spearman's } \\
\text { rank-order } \\
\text { correlation } \\
\text { (p-value) }\end{array}$ & $\begin{array}{c}\text { U-Mann- } \\
\text { Whitney } \\
\text { Test (p-value) }\end{array}$ & Conclusion \\
\hline \multicolumn{6}{|l|}{ Objective factors } \\
\hline Farm location & $\begin{array}{l}\text { H1_1: Perception of } \\
\text { drought risk depends on } \\
\text { the farm's location. }\end{array}$ & $2,34(0,311)$ & $\mathrm{NA}$ & NA & $\begin{array}{l}\text { The findings contradict } \\
\text { the research hypothesis. }\end{array}$ \\
\hline $\begin{array}{l}\text { Average } \\
\text { monthly income } \\
\text { from farming } \\
\text { operations }\end{array}$ & $\begin{array}{l}\text { H1_2: The higher the } \\
\text { monthly income from } \\
\text { farming operations, } \\
\text { the higher the risk } \\
\text { perception }\end{array}$ & $16,73(0,005)$ & $0,2(0,021)$ & $\begin{array}{l}164(0,006) \text { for } \\
\text { groups up to } \\
2 \mathrm{~K} \text {. and } 4001- \\
6 \mathrm{~K} \text {. } \\
54(0,05) \text { for } \\
\text { groups up to } 2 \\
\mathrm{~K} \text { and } 6001-8 \\
\mathrm{~K} \text {. } \\
0(0,008) \text { for } \\
\text { groups up to } 2 \\
\mathrm{~K} \text { and } 8001- \\
12 \mathrm{~K} \text {. } \\
756,5(0,024) \\
\text { for groups betw. } \\
4001-6 \mathrm{~K} \text { and } \\
4001-6 \mathrm{~K} \text {. } \\
4,0(0,007) \text { for } \\
\text { groups betw. } \\
2001-4 \mathrm{~K} \text { and } \\
8001 \text { to } 12 \mathrm{~K} \text {. } \\
22,5(0,034) \text { for } \\
\text { groups } 4001 \text { to } \\
6 \mathrm{~K} \text { and } 8001- \\
12 \mathrm{~K} \text {. } \\
7(0,06) \text { for } \\
\text { groups } 6001-8 \\
\mathrm{~K} \text { and } 8001- \\
12 \mathrm{~K} \text {. }\end{array}$ & $\begin{array}{l}\text { The findings contradict } \\
\text { the research hypothesis. } \\
\text { The highest risk } \\
\text { perception is among } \\
\text { farmers with income } \\
\text { from } 8001 \text { PLN to } 12 \\
\text { thousand PLN. }\end{array}$ \\
\hline Farm size & $\begin{array}{l}\text { H1_3: The greater the } \\
\text { amount of arable land, } \\
\text { the higher the risk } \\
\text { perception. }\end{array}$ & $8,80(0,012)$ & $0,74(0,32)$ & $\begin{array}{l}916(0,09) \text { for } \\
\text { groups from } 1 \\
\text { ha }-5 \text { ha and } \\
20,1 \text { ha }-50 \text { ha } \\
477(0,08) \text { for } \\
\text { groups } 5,1 \text { ha }- \\
20 \text { ha and } 20,1 \\
\text { ha }-50 \text { ha }\end{array}$ & $\begin{array}{l}\text { The findings are } \\
\text { ambiguous. } \\
\text { Although the highest } \\
\text { level of risk perception } \\
\text { was observed in } \\
\text { farms of more than } \\
20 \text { ha, there were no } \\
\text { differences between } \\
\text { other categories of farm } \\
\text { size. }\end{array}$ \\
\hline Soil class & $\begin{array}{l}\text { H1_4: The higher the } \\
\text { average soil class in a } \\
\text { given farm, the lower } \\
\text { the risk perception }\end{array}$ & NA & $0,044(0,541)$ & & $\begin{array}{l}\text { The findings contradict } \\
\text { the research hypothesis. }\end{array}$ \\
\hline
\end{tabular}


ERAZ 2019

Selected Papers

\begin{tabular}{|c|c|c|c|c|c|}
\hline Variable & Hypothesis & $\begin{array}{l}\text { Kruskal- } \\
\text { Wallis } \\
\text { Test } \\
\text { (p-value) }\end{array}$ & $\begin{array}{l}\text { Spearman's } \\
\text { rank-order } \\
\text { correlation } \\
\text { (p-value) } \\
\end{array}$ & $\begin{array}{c}\text { U-Mann- } \\
\text { Whitney } \\
\text { Test (p-value) }\end{array}$ & Conclusion \\
\hline $\begin{array}{l}\text { Type of annual } \\
\text { crops }\end{array}$ & $\begin{array}{l}\text { H1_5_1: Drought risk } \\
\text { perception is dependent } \\
\text { on the type of cultivated } \\
\text { annual crops. }\end{array}$ & NA & NA & $\begin{array}{l}3420,5(0,001) \\
\text { for triticale } \\
81,0(0,033) \text { for } \\
\text { sugar beet }\end{array}$ & $\begin{array}{l}\text { The findings corroborate } \\
\text { the research hypothesis } \\
\text { in the case of winter } \\
\text { triticale cultivation } \\
\text { (lower risk perception } \\
\text { for farmers who grow } \\
\text { triticale), sugar beet } \\
\text { (higher risk perception } \\
\text { for farmers who grow } \\
\text { sugar beet) }\end{array}$ \\
\hline $\begin{array}{l}\text { Multi-annual } \\
\text { plants }\end{array}$ & $\begin{array}{l}\text { H1_5_2: Drought risk } \\
\text { perception is dependent } \\
\text { on the type of cultivated } \\
\text { plants (annual or multi- } \\
\text { annual). }\end{array}$ & NA & NA & $261(0,085)$ & $\begin{array}{l}\text { The findings contradict } \\
\text { the research hypothesis. }\end{array}$ \\
\hline $\begin{array}{l}\text { Farm } \\
\text { specialisation }\end{array}$ & $\begin{array}{l}\text { H1_6: farmers } \\
\text { managing farms which } \\
\text { specialise in plant } \\
\text { output perceive drought } \\
\text { risk as higher than } \\
\text { those managing farms } \\
\text { with other types of } \\
\text { specialisations. }\end{array}$ & $22,98(0,000)$ & NA & $\begin{array}{l}1594,5(0,000) \\
\text { in groups ref. } \\
\text { Plant output } \\
\text { and milk } \\
285,0(0,001) \\
\text { in groups } \\
\text { ref. Plant } \\
\text { output and no } \\
\text { specialisation } \\
710,5(0,004) \text { in } \\
\text { groups ref. pork } \\
\text { and milk } \\
148,9(0,015) \\
\text { in groups ref. } \\
\text { pork and no } \\
\text { specialisation. }\end{array}$ & $\begin{array}{l}\text { The findings } \\
\text { corroborate the research } \\
\text { hypothesis. } \\
\text { With ,plant output” } \\
\text { specialisation farmers } \\
\text { perceive drought risk as } \\
\text { the highest. }\end{array}$ \\
\hline $\begin{array}{l}\text { Share of income } \\
\text { from farming } \\
\text { operations }\end{array}$ & $\begin{array}{l}\text { H1_7: The higher the } \\
\text { share of income from } \\
\text { farming in the whole } \\
\text { income, the higher the } \\
\text { risk perception. }\end{array}$ & NA & $0,21(0,003)$ & & $\begin{array}{l}\text { Findings point to } \\
\text { existence and positive } \\
\text { direction of the } \\
\text { correlation. }\end{array}$ \\
\hline \multicolumn{6}{|l|}{ Subjective factors } \\
\hline $\begin{array}{l}\text { Average loss in } \\
\text { crops caused by } \\
\text { drought }\end{array}$ & $\begin{array}{l}\text { H1_8: The higher the } \\
\text { average loss in farm's } \\
\text { crops caused by drought } \\
\text { in the previous year, the } \\
\text { higher the drought risk } \\
\text { perception }\end{array}$ & NA & $0,258(0,000)$ & & $\begin{array}{l}\text { The findings } \\
\text { corroborate the research } \\
\text { hypothesis. }\end{array}$ \\
\hline $\begin{array}{l}\text { Average loss in } \\
\text { income caused } \\
\text { by drought }\end{array}$ & $\begin{array}{l}\text { H1_9: The higher the } \\
\text { average loss in farm's } \\
\text { income caused by } \\
\text { drought in the previous } \\
\text { year, the higher the } \\
\text { drought risk perception }\end{array}$ & NA & $0,42(0,000)$ & & $\begin{array}{l}\text { The findings } \\
\text { corroborate the research } \\
\text { hypothesis. }\end{array}$ \\
\hline $\begin{array}{l}\text { Reduction in } \\
\text { amount or } \\
\text { quality of yield } \\
\text { in annual crops } \\
\text { (frequency) }\end{array}$ & $\begin{array}{l}\text { H1_10_1: Impact of } \\
\text { experience on drought } \\
\text { risk perception depends } \\
\text { on the frequency of } \\
\text { reduction in amount or } \\
\text { quality of yield. }\end{array}$ & NA & $-0,14(0,060)$ & & $\begin{array}{l}\text { The findings contradict } \\
\text { the research hypothesis. }\end{array}$ \\
\hline
\end{tabular}




\begin{tabular}{|c|c|c|c|c|c|}
\hline Variable & Hypothesis & $\begin{array}{c}\text { Kruskal- } \\
\text { Wallis } \\
\text { Test } \\
\text { (p-value) }\end{array}$ & $\begin{array}{c}\text { Spearman's } \\
\text { rank-order } \\
\text { correlation } \\
\text { (p-value) } \\
\end{array}$ & $\begin{array}{c}\text { U-Mann- } \\
\text { Whitney } \\
\text { Test (p-value) }\end{array}$ & Conclusion \\
\hline $\begin{array}{l}\text { Reduction } \\
\text { in amount of } \\
\text { yield in multi- } \\
\text { annual crops } \\
\text { (frequency) }\end{array}$ & $\begin{array}{l}\text { H1_10_2: Impact of } \\
\text { experience on drought } \\
\text { risk perception depends } \\
\text { on the frequency of } \\
\text { reduction in amount of } \\
\text { yield in multi-annual } \\
\text { crops }\end{array}$ & NA & $-0,13(0,066)$ & & $\begin{array}{l}\text { The findings contradict } \\
\text { the research hypothesis. }\end{array}$ \\
\hline $\begin{array}{l}\text { Reduction in } \\
\text { yield of } 30 \% \\
\text { or more of } \\
\text { regular output } \\
\text { (frequency) }\end{array}$ & $\begin{array}{l}\text { H1_10_3: Impact of } \\
\text { experience on drought } \\
\text { risk perception depends } \\
\text { on the frequency of } \\
\text { reduction in yield of } \\
\text { more than } 30 \%\end{array}$ & NA & $-0,02(0,814)$ & & $\begin{array}{l}\text { The findings contradict } \\
\text { the research hypothesis. }\end{array}$ \\
\hline $\begin{array}{l}\text { Reduction in } \\
\text { the amount of } \\
\text { water available } \\
\text { for irrigation } \\
\text { (frequency) }\end{array}$ & $\begin{array}{l}\text { H1_10_4: Impact of } \\
\text { experience on drought } \\
\text { risk perception depends } \\
\text { on the frequency of } \\
\text { reduction in the amount } \\
\text { of water for irrigation }\end{array}$ & NA & $0,07(0,344)$ & & $\begin{array}{l}\text { The findings contradict } \\
\text { the research hypothesis. }\end{array}$ \\
\hline $\begin{array}{l}\text { Reduction in } \\
\text { the animal } \\
\text { output } \\
\text { (frequency) }\end{array}$ & $\begin{array}{l}\text { H1_10_5: Impact of } \\
\text { experience on drought } \\
\text { risk perception depends } \\
\text { on the frequency of } \\
\text { reduction in animal } \\
\text { output }\end{array}$ & NA & $0,07(0,332)$ & & $\begin{array}{l}\text { The findings contradict } \\
\text { the research hypothesis. }\end{array}$ \\
\hline $\begin{array}{l}\text { Enforced herd } \\
\text { reduction } \\
\text { (frequency) }\end{array}$ & $\begin{array}{l}\text { H1_10_6: Impact of } \\
\text { experience on drought } \\
\text { risk perception depends } \\
\text { on the frequency of } \\
\text { enforced herd reduction. }\end{array}$ & NA & $-0,13(0,068)$ & & $\begin{array}{l}\text { The findings contradict } \\
\text { the research hypothesis. }\end{array}$ \\
\hline $\begin{array}{l}\text { Local shortage } \\
\text { of animal } \\
\text { feed or water } \\
\text { (frequency) }\end{array}$ & $\begin{array}{l}\text { H1_10_7: Impact of } \\
\text { experience on drought } \\
\text { risk perception depends } \\
\text { on the frequency of } \\
\text { local shortage of animal } \\
\text { feed or water. }\end{array}$ & NA & $0,02(0,811)$ & & $\begin{array}{l}\text { The findings contradict } \\
\text { the research hypothesis. }\end{array}$ \\
\hline $\begin{array}{l}\text { Increase in } \\
\text { tension (rows) } \\
\text { in the family } \\
\text { (frequency) }\end{array}$ & $\begin{array}{l}\text { H1_10_8: Impact of } \\
\text { experience on drought } \\
\text { risk perception depends } \\
\text { on the frequency of } \\
\text { increasing tensions in } \\
\text { the family }\end{array}$ & NA & $0,01(0,924)$ & & $\begin{array}{l}\text { The findings contradict } \\
\text { the research hypothesis. }\end{array}$ \\
\hline $\begin{array}{l}\text { Family } \\
\text { members' } \\
\text { health issues } \\
\text { (frequency) }\end{array}$ & $\begin{array}{l}\text { H1_10_9: Impact of } \\
\text { experience on drought } \\
\text { risk perception depends } \\
\text { on the frequency of } \\
\text { health issues in family } \\
\text { members }\end{array}$ & NA & $-0,09(0,227)$ & & $\begin{array}{l}\text { The findings contradict } \\
\text { the research hypothesis. }\end{array}$ \\
\hline $\begin{array}{l}\text { Shortage of } \\
\text { drinking water } \\
\text { for humans } \\
\text { (frequency) }\end{array}$ & $\begin{array}{l}\text { H1_10_10: Impact of } \\
\text { experience on drought } \\
\text { risk perception depends } \\
\text { on the frequency of } \\
\text { shortage of drinking } \\
\text { water for humans. }\end{array}$ & NA & $0,03(0,725)$ & & $\begin{array}{l}\text { The findings contradict } \\
\text { the research hypothesis. }\end{array}$ \\
\hline $\begin{array}{l}\text { Soil erosion } \\
\text { (frequency) }\end{array}$ & $\begin{array}{l}\text { H1_10_11: Impact of } \\
\text { experience on drought } \\
\text { risk perception depends } \\
\text { on the frequency of soil } \\
\text { erosion. }\end{array}$ & NA & $0,07(0,323)$ & & $\begin{array}{l}\text { The findings contradict } \\
\text { the research hypothesis. }\end{array}$ \\
\hline
\end{tabular}


ERAZ 2019

Selected Papers

\begin{tabular}{|c|c|c|c|c|c|}
\hline Variable & Hypothesis & $\begin{array}{l}\text { Kruskal- } \\
\text { Wallis } \\
\text { Test } \\
\text { (p-value) }\end{array}$ & $\begin{array}{c}\text { Spearman's } \\
\text { rank-order } \\
\text { correlation } \\
\text { (p-value) }\end{array}$ & $\begin{array}{c}\text { U-Mann- } \\
\text { Whitney } \\
\text { Test (p-value) }\end{array}$ & Conclusion \\
\hline $\begin{array}{l}\text { Fires in } \\
\text { the farm } \\
\text { (frequency) }\end{array}$ & $\begin{array}{l}\text { H1_10_12: Impact of } \\
\text { experience on drought } \\
\text { risk perception depends } \\
\text { on the frequency of fires } \\
\text { in the farm. }\end{array}$ & NA & $-0,15(0,038)$ & & $\begin{array}{l}\text { The findings } \\
\text { corroborate the research } \\
\text { hypothesis. }\end{array}$ \\
\hline $\begin{array}{l}\text { Reduction } \\
\text { in the farm's } \\
\text { income } \\
\text { (frequency) }\end{array}$ & $\begin{array}{l}\text { H1_10_13: Impact of } \\
\text { experience on drought } \\
\text { risk perception depends } \\
\text { on the frequency of } \\
\text { reduction in the farm's } \\
\text { income }\end{array}$ & NA & $-0,10(0,172)$ & & $\begin{array}{l}\text { The findings contradict } \\
\text { the research hypothesis. }\end{array}$ \\
\hline $\begin{array}{l}\text { Increase } \\
\text { in costs of } \\
\text { agricultural } \\
\text { measures } \\
\text { (frequency) }\end{array}$ & $\begin{array}{l}\text { H1_10_14: Impact of } \\
\text { experience on drought } \\
\text { risk perception depends } \\
\text { on the frequency of } \\
\text { increase in costs of } \\
\text { agricultural measures }\end{array}$ & NA & $0,08(0,263)$ & & $\begin{array}{l}\text { The findings contradict } \\
\text { the research hypothesis. }\end{array}$ \\
\hline $\begin{array}{l}\text { Reduction } \\
\text { in financial } \\
\text { liquidity } \\
\text { (frequency) }\end{array}$ & $\begin{array}{l}\text { H1_10_15: Impact of } \\
\text { experience on drought } \\
\text { risk perception depends } \\
\text { on the frequency of } \\
\text { reduction in financial } \\
\text { liquidity. } \\
\end{array}$ & NA & $0,034(0,634)$ & & $\begin{array}{l}\text { The findings contradict } \\
\text { the research hypothesis. }\end{array}$ \\
\hline $\begin{array}{l}\text { Decrease in } \\
\text { investments } \\
\text { (frequency) }\end{array}$ & $\begin{array}{l}\text { H1_10_16: Impact of } \\
\text { experience on drought } \\
\text { risk perception depends } \\
\text { on the frequency of } \\
\text { decrease in investments. }\end{array}$ & NA & $0,11(0,146)$ & & $\begin{array}{l}\text { The findings contradict } \\
\text { the research hypothesis. }\end{array}$ \\
\hline $\begin{array}{l}\text { Difficulty in } \\
\text { obtaining loans } \\
\text { (frequency) }\end{array}$ & $\begin{array}{l}\text { H1_10_17: Impact of } \\
\text { experience on drought } \\
\text { risk perception depends } \\
\text { on the frequency of } \\
\text { difficulty in obtaining } \\
\text { loans }\end{array}$ & NA & $-0,17(0,015)$ & & $\begin{array}{l}\text { The findings } \\
\text { corroborate the research } \\
\text { hypothesis. }\end{array}$ \\
\hline $\begin{array}{l}\text { Lowering of } \\
\text { the family's } \\
\text { standard } \\
\text { of living } \\
\text { (frequency) }\end{array}$ & $\begin{array}{l}\text { H1_10_18: Impact of } \\
\text { experience on drought } \\
\text { risk perception depends } \\
\text { on the frequency of } \\
\text { lowering the family's } \\
\text { standard of living. }\end{array}$ & NA & $-0,23(0,001)$ & & $\begin{array}{l}\text { The findings } \\
\text { corroborate the research } \\
\text { hypothesis. }\end{array}$ \\
\hline $\begin{array}{l}\text { Conflicts with } \\
\text { recipients } \\
\text { (frequency) }\end{array}$ & $\begin{array}{l}\text { H1_10_19: Impact of } \\
\text { experience on drought } \\
\text { risk perception depends } \\
\text { on the frequency of } \\
\text { conflicts with recipients. }\end{array}$ & NA & $-0,18(0,011)$ & & $\begin{array}{l}\text { The findings } \\
\text { corroborate the research } \\
\text { hypothesis. }\end{array}$ \\
\hline $\begin{array}{l}\text { Level of fear } \\
\text { caused by } \\
\text { drought }\end{array}$ & $\begin{array}{l}\text { H1_11_1: The higher the } \\
\text { level of fear caused by } \\
\text { drought the higher the } \\
\text { drought risk perception }\end{array}$ & NA & $-0,07(0,363)$ & & $\begin{array}{l}\text { The findings contradict } \\
\text { the research hypothesis. }\end{array}$ \\
\hline $\begin{array}{l}\text { Risk } \\
\text { controllability } \\
\text { _knowledge }\end{array}$ & $\begin{array}{l}\text { H1_11_2: The stronger } \\
\text { the respondent's feeling } \\
\text { that they have sufficient } \\
\text { knowledge to control } \\
\text { drought risk the weaker } \\
\text { the perception of this } \\
\text { risk. }\end{array}$ & NA & $-0,043(0,555)$ & & $\begin{array}{l}\text { The findings contradict } \\
\text { the research hypothesis. }\end{array}$ \\
\hline
\end{tabular}




\begin{tabular}{|c|c|c|c|c|c|}
\hline Variable & Hypothesis & $\begin{array}{l}\text { Kruskal- } \\
\text { Wallis } \\
\text { Test } \\
\text { (p-value) } \\
\end{array}$ & $\begin{array}{l}\text { Spearman's } \\
\text { rank-order } \\
\text { correlation } \\
\text { (p-value) } \\
\end{array}$ & $\begin{array}{c}\text { U-Mann- } \\
\text { Whitney } \\
\text { Test (p-value) }\end{array}$ & Conclusion \\
\hline $\begin{array}{l}\text { Risk } \\
\text { controllability } \\
\text { resources }\end{array}$ & $\begin{array}{l}\text { H1_11_3: The stronger } \\
\text { the respondent's feeling } \\
\text { that they possess } \\
\text { sufficient material } \\
\text { and financial means } \\
\text { to control drought the } \\
\text { lower the perception of } \\
\text { this risk }\end{array}$ & NA & $-0,10(0,176)$ & & $\begin{array}{l}\text { The findings contradict } \\
\text { the research hypothesis. }\end{array}$ \\
\hline $\begin{array}{l}\text { Catastrophic } \\
\text { impact_scope }\end{array}$ & $\begin{array}{l}\text { H1_11_4: The stronger } \\
\text { the feeling that the } \\
\text { impact of drought } \\
\text { may be catastrophic, } \\
\text { the higher the risk } \\
\text { perception. }\end{array}$ & NA & $-0,069(0,341)$ & & $\begin{array}{l}\text { The findings contradict } \\
\text { the research hypothesis. }\end{array}$ \\
\hline $\begin{array}{l}\text { Catastrophic } \\
\text { impact_- } \\
\text { probability }\end{array}$ & $\begin{array}{l}\text { H1_11_5: The higher } \\
\text { the assessment } \\
\text { of probability of } \\
\text { catastrophic impact of } \\
\text { drought, the higher the } \\
\text { risk perception }\end{array}$ & NA & $-0,1(0,159)$ & & $\begin{array}{l}\text { The findings contradict } \\
\text { the research hypothesis. }\end{array}$ \\
\hline $\begin{array}{l}\text { Severity of the } \\
\text { impact }\end{array}$ & $\begin{array}{l}\text { H1_11_6: The stronger } \\
\text { the conviction that } \\
\text { drought may threaten } \\
\text { the farm survival, } \\
\text { the higher the risk } \\
\text { perception. }\end{array}$ & NA & $0,272(0,000)$ & & $\begin{array}{l}\text { The findings } \\
\text { corroborate the research } \\
\text { hypothesis. }\end{array}$ \\
\hline $\begin{array}{l}\text { Risk familiar to } \\
\text { the farmer }\end{array}$ & $\begin{array}{l}\text { H1_11_7: The stronger } \\
\text { the farmer's conviction } \\
\text { that drought is a } \\
\text { familiar phenomenon, } \\
\text { the weaker the risk } \\
\text { perception. }\end{array}$ & NA & $-0,085(0,22)$ & & $\begin{array}{l}\text { The findings contradict } \\
\text { the research hypothesis. }\end{array}$ \\
\hline $\begin{array}{l}\text { Risk well- } \\
\text { known to } \\
\text { science }\end{array}$ & $\begin{array}{l}\text { H1_11_8: The stronger } \\
\text { the conviction } \\
\text { that drought is a } \\
\text { phenomenon known to } \\
\text { science the weaker the } \\
\text { risk perception. }\end{array}$ & NA & $0,292(0,004)$ & & $\begin{array}{l}\text { The findings } \\
\text { corroborate the research } \\
\text { hypothesis. }\end{array}$ \\
\hline $\begin{array}{l}\text { Visibility of } \\
\text { impact }\end{array}$ & $\begin{array}{l}\text { H11 9: The stronger the } \\
\text { feeling that the impact } \\
\text { of drought is not hidden } \\
\text { (visible with ,the naked } \\
\text { eye"), the lower the risk } \\
\text { perception. }\end{array}$ & NA & $-0,09(0,210)$ & & $\begin{array}{l}\text { The findings contradict } \\
\text { the research hypothesis. }\end{array}$ \\
\hline $\begin{array}{l}\text { Immediacy } \\
\text { effect }\end{array}$ & $\begin{array}{l}\text { H1_11_10: The stronger } \\
\text { the conviction that the } \\
\text { impact of water shortage } \\
\text { can be seen only after } \\
\text { some time, the lower the } \\
\text { risk perception. }\end{array}$ & NA & $-0,210(0,03)$ & & $\begin{array}{l}\text { The findings } \\
\text { corroborate the research } \\
\text { hypothesis. }\end{array}$ \\
\hline Newness of risk & $\begin{array}{l}\text { H1_11_11: The stronger } \\
\text { the conviction that } \\
\text { drought is an old } \\
\text { and well-known } \\
\text { phenomenon the weaker } \\
\text { the risk perception. }\end{array}$ & NA & $0,081(0,243)$ & & $\begin{array}{l}\text { The findings contradict } \\
\text { the research hypothesis. }\end{array}$ \\
\hline
\end{tabular}


ERAZ 2019

Selected Papers

\begin{tabular}{|c|c|c|c|c|c|}
\hline Variable & Hypothesis & $\begin{array}{l}\text { Kruskal- } \\
\text { Wallis } \\
\text { Test } \\
\text { (p-value) }\end{array}$ & $\begin{array}{c}\text { Spearman's } \\
\text { rank-order } \\
\text { correlation } \\
\text { (p-value) }\end{array}$ & $\begin{array}{c}\text { U-Mann- } \\
\text { Whitney } \\
\text { Test (p-value) }\end{array}$ & Conclusion \\
\hline $\begin{array}{l}\text { Common } \\
\text { exposure to risk }\end{array}$ & $\begin{array}{l}\text { H1_11_12: The } \\
\text { larger the number of } \\
\text { farms which in the } \\
\text { respondent's opinion } \\
\text { are exposed to drought, } \\
\text { the higher the risk } \\
\text { perception. }\end{array}$ & NA & $-0,236(0,029)$ & & $\begin{array}{l}\text { The findings contradict } \\
\text { the research hypothesis. } \\
\text { The larger the number } \\
\text { of farms which in the } \\
\text { respondent's opinion } \\
\text { are exposed to drought, } \\
\text { the lower the risk } \\
\text { perception is. }\end{array}$ \\
\hline $\begin{array}{l}\text { Susceptibility } \\
\text { to others' } \\
\text { opinions }\end{array}$ & $\begin{array}{l}\text { H1_12: The more } \\
\text { important the farm } \\
\text { manager finds the other } \\
\text { farmers' opinion about } \\
\text { the choice of tools for } \\
\text { preventing the impact of } \\
\text { drought, the higher the } \\
\text { drought risk perception. }\end{array}$ & NA & $-0,061(0,398)$ & & $\begin{array}{l}\text { The findings contradict } \\
\text { the research hypothesis. }\end{array}$ \\
\hline \begin{tabular}{|l|} 
Trust_existence \\
of the system
\end{tabular} & $\begin{array}{l}\text { H1_13_1: Conviction } \\
\text { that there is a system of } \\
\text { drought management } \\
\text { in Poland lowers the } \\
\text { drought risk perception. }\end{array}$ & NA & NA & $1,53(0,465)$ & $\begin{array}{l}\text { The findings contradict } \\
\text { the research hypothesis. }\end{array}$ \\
\hline $\begin{array}{l}\text { Trust _ } \\
\text { understanding } \\
\text { of CWB }\end{array}$ & $\begin{array}{l}\text { H1_13_2: } \\
\text { Understanding of CWB } \\
\text { indicator lowers the } \\
\text { drought risk perception. }\end{array}$ & $\mathrm{NA}$ & $\mathrm{NA}$ & $1,50(0,470)$ & $\begin{array}{l}\text { The findings contradict } \\
\text { the research hypothesis. }\end{array}$ \\
\hline $\begin{array}{l}\text { Trust } \\
\text { accuracy of } \\
\text { CWB }\end{array}$ & $\begin{array}{l}\text { H1_13_3: The stronger } \\
\text { the conviction that } \\
\text { CWB indicator properly } \\
\text { reflects drought } \\
\text { occurrences, the lower } \\
\text { the risk perception. }\end{array}$ & NA & $0,027(0,756)$ & & $\begin{array}{l}\text { The findings contradict } \\
\text { the research hypothesis. }\end{array}$ \\
\hline $\begin{array}{l}\text { Trust_CWB } \\
\text { measurements }\end{array}$ & $\begin{array}{l}\text { H1_13_4: The stronger } \\
\text { the feeling that CWB } \\
\text { measurements can be } \\
\text { trusted the lower the } \\
\text { risk perception. }\end{array}$ & NA & $0,31(0,721)$ & & $\begin{array}{l}\text { The findings contradict } \\
\text { the research hypothesis. }\end{array}$ \\
\hline $\begin{array}{l}\text { Trust_farmers' } \\
\text { interest }\end{array}$ & $\begin{array}{l}\text { H1_13_5: The stronger } \\
\text { the conviction that } \\
\text { farmers have sufficient } \\
\text { say in conducting } \\
\text { operations minimising } \\
\text { the impact of drought } \\
\text { the lower the risk } \\
\text { perception. }\end{array}$ & NA & $-0,02(0,780)$ & & $\begin{array}{l}\text { The findings contradict } \\
\text { the research hypothesis. }\end{array}$ \\
\hline Trust_experts & $\begin{array}{l}\text { H1_13_6: The higher the } \\
\text { level of trust in experts' } \\
\text { opinion about the scope } \\
\text { of drought, its causes } \\
\text { and necessary actions, } \\
\text { the lower the risk } \\
\text { perception. }\end{array}$ & NA & $-0,22(0,02)$ & & $\begin{array}{l}\text { The findings } \\
\text { corroborate the research } \\
\text { hypothesis. }\end{array}$ \\
\hline \begin{tabular}{|l|} 
Trust_the state \\
\end{tabular} & $\begin{array}{l}\text { H1_13_7: The stronger } \\
\text { the conviction that the } \\
\text { state guards the farmers' } \\
\text { interests with respect to } \\
\text { drought, the lower the } \\
\text { risk perception. }\end{array}$ & NA & $0,05(0,498)$ & & $\begin{array}{l}\text { The findings contradict } \\
\text { the research hypothesis. }\end{array}$ \\
\hline
\end{tabular}




\begin{tabular}{|c|c|c|c|c|c|}
\hline Variable & Hypothesis & $\begin{array}{l}\text { Kruskal- } \\
\text { Wallis } \\
\text { Test } \\
\text { (p-value) }\end{array}$ & $\begin{array}{c}\text { Spearman's } \\
\text { rank-order } \\
\text { correlation } \\
\text { (p-value) }\end{array}$ & $\begin{array}{c}\text { U-Mann- } \\
\text { Whitney } \\
\text { Test (p-value) }\end{array}$ & Conclusion \\
\hline Trust_media & $\begin{array}{l}\text { H1_14: The higher the } \\
\text { level of trust in the } \\
\text { media informing about } \\
\text { drought, the lower the } \\
\text { risk perception. }\end{array}$ & $\mathrm{NA}$ & $-0,154(0,029)$ & & $\begin{array}{l}\text { The findings } \\
\text { corroborate the research } \\
\text { hypothesis. }\end{array}$ \\
\hline Age & $\begin{array}{l}\text { H1_15: The older the } \\
\text { person in charge of the } \\
\text { farm, the lower the risk } \\
\text { perception. }\end{array}$ & $15,09(0,02)$ & $-0,77(0,282)$ & $\begin{array}{l}473,5(0,044) \\
\text { between groups } \\
\text { aged } 31-35 \text { and } \\
51-55 \\
262,5(0,053) \\
\text { between groups } \\
\text { aged } 36-40 \text { and } \\
41-45 \\
65,0(0,008) \\
\text { between groups } \\
\text { aged } 36-40 \text { and } \\
56-60 \\
544(0,002) \\
\text { between groups } \\
\text { aged } 41-45 \text { and } \\
51-55 \\
177(0,002) \\
\text { between groups } \\
\text { aged } 51-55 \text { and } \\
\text { over } 56-60 .\end{array}$ & $\begin{array}{l}\text { The findings contradict } \\
\text { the research hypothesis. } \\
\text { Although there is a } \\
\text { correlation between age } \\
\text { and risk perception, } \\
\text { but it was impossible } \\
\text { to determine its } \\
\text { unambiguous direction. }\end{array}$ \\
\hline Gender & $\begin{array}{l}\text { H1_16: Women have a } \\
\text { higher perception of risk } \\
\text { than men. }\end{array}$ & $0,549(0,459)$ & $\mathrm{NA}$ & & $\begin{array}{l}\text { The findings contradict } \\
\text { the research hypothesis. }\end{array}$ \\
\hline Education_level & $\begin{array}{l}\text { H1_17_1: The higher } \\
\text { the education level, } \\
\text { the higher the risk } \\
\text { perception. }\end{array}$ & $6,22(0,045)$ & $-0,088(0,22)$ & \begin{tabular}{|l|}
$2866(0,040)$ \\
between groups \\
with vocational \\
or lower, and \\
secondary \\
$127,0(0,069)$ \\
between groups \\
with secondary \\
and post- \\
secondary
\end{tabular} & $\begin{array}{l}\text { The findings contradict } \\
\text { the research hypothesis. } \\
\text { The lowest level is } \\
\text { seen in farmers with } \\
\text { vocational education } \\
\text { or lower, the highest } \\
\text { in farmers with post- } \\
\text { secondary education. }\end{array}$ \\
\hline $\begin{array}{l}\text { Education } \\
\text { type }\end{array}$ & $\begin{array}{l}\text { H1_17_2: Agricultural } \\
\text { education lowers the } \\
\text { drought risk perception. }\end{array}$ & $\mathrm{NA}$ & NA & $4567(0,674)$ & $\begin{array}{l}\text { The findings contradict } \\
\text { the research hypothesis. }\end{array}$ \\
\hline
\end{tabular}

Source: Author's own research 
Table 2. Findings of the regression analysis of drought risk perception for three groups of exogenous variables

\begin{tabular}{|c|c|c|c|c|c|c|}
\hline \multirow{2}{*}{ Variables } & \multicolumn{2}{|c|}{$\begin{array}{l}\text { Model } 1 \text { - objective } \\
\text { factors }\end{array}$} & \multicolumn{2}{|c|}{$\begin{array}{l}\text { Model } 2 \text {-subjective } \\
\text { factors }\end{array}$} & \multicolumn{2}{|c|}{$\begin{array}{l}\text { Model } 3 \text { - both objective } \\
\text { and subjective factors }\end{array}$} \\
\hline & Coefficient & $\begin{array}{l}\text { Standard } \\
\text { deviation }\end{array}$ & Coefficient & $\begin{array}{l}\text { Standard } \\
\text { deviation }\end{array}$ & Coefficient & $\begin{array}{l}\text { Standard } \\
\text { deviation }\end{array}$ \\
\hline Constant & $7,7 * * *$ & 0,62 & $9,79 * * *$ & 2,42 & $8,84^{* * *}$ & 2,37 \\
\hline Farm's specialisation - plant output & $2,59 * * *$ & 0,82 & & & $0,95 * *$ & 0,46 \\
\hline Farm's specialisation - livestock & $2,51 * *$ & 1,07 & & & 0,73 & 0,54 \\
\hline $\begin{array}{l}\text { Average monthly income from } \\
\text { farming operations - from } 2001 \text { to } \\
4000\end{array}$ & $-1,90 * *$ & 0,93 & & & 1,03 & 0,64 \\
\hline $\begin{array}{l}\text { Average monthly income from } \\
\text { farming operations - over } 12 \mathrm{~K}\end{array}$ & $3,71^{* *}$ & 1,60 & & & $-1,34$ & 0,93 \\
\hline Age 31-35 & & & $2,62 * * *$ & 0,67 & $2,87 * * *$ & 0,68 \\
\hline Age 41-45 & & & $1,31 * *$ & 0,59 & $1,47 * *$ & 0,58 \\
\hline \begin{tabular}{|l|l|} 
Age 46-50 \\
\end{tabular} & & & $2,56^{* * *}$ & 0,68 & $3.06^{* * *}$ & 0,70 \\
\hline Age 51-55 & & & $-2,37 * * *$ & 0,61 & $-2.07 * * *$ & 0,60 \\
\hline Education_level secondary & & & $-1,33 * * *$ & 0,47 & $-1,11 * *$ & 0,47 \\
\hline $\begin{array}{l}\text { Average loss in yield caused by } \\
\text { drought }\end{array}$ & & & $0,07 * * *$ & 0,02 & $0,06 * * *$ & 0,02 \\
\hline $\begin{array}{l}\text { Average loss in income caused by } \\
\text { drought }\end{array}$ & & & $0,085 * * *$ & 0,02 & $0,10 * * *$ & 0,02 \\
\hline $\begin{array}{l}\text { Reduction in yield in multi-annual } \\
\text { crops (frequency) }\end{array}$ & & & $0,35 * *$ & 0,16 & 0,24 & 0,17 \\
\hline \begin{tabular}{|l|}
$\begin{array}{l}\text { Reduction in the farm's income } \\
\text { (frequency) }\end{array}$ \\
\end{tabular} & & & $-0,77^{* * *}$ & 0,16 & $-0,76^{* * *}$ & 0,15 \\
\hline \begin{tabular}{|l|}
$\begin{array}{l}\text { Reduction in investments } \\
\text { (frequency) }\end{array}$ \\
\end{tabular} & & & $0,94^{* * *}$ & 0,17 & $0,94 * * *$ & 0,17 \\
\hline \begin{tabular}{|l|}
$\begin{array}{l}\text { Difficulties with obtaining loans } \\
\text { (frequency) }\end{array}$ \\
\end{tabular} & & & $-0,98 * * *$ & 0,15 & $-0,96^{* * *}$ & 0,15 \\
\hline \begin{tabular}{|l|} 
Risk controllability_resources \\
\end{tabular} & & & $-0,72 * * *$ & 0,15 & $-0,53 * * *$ & 0,16 \\
\hline Impact severity (survival) & & & $0,91 * * *$ & 0,16 & $0,81 * * *$ & 0,16 \\
\hline Immediacy of effect & & & $-0,58 * * *$ & 0,20 & $-0,60 * * *$ & 0,20 \\
\hline Trust_system existence & & & $-2,59 * * *$ & 0,85 & $-2,46^{* * *}$ & 0,83 \\
\hline Trust_understanding CWB & & & $-1,23 * *$ & 0,53 & $-1,72 * * *$ & 0,54 \\
\hline Trust_CWB accuracy & & & $-0,58^{* * *}$ & 0,19 & $-0,53 * * *$ & 0,12 \\
\hline $\begin{array}{l}\mathbf{R}^{2} \\
\text { Corrected } \mathbf{R}^{2} \\
\text { F (p-value) }\end{array}$ & \multicolumn{2}{|c|}{$\begin{array}{l}0,084 \\
0,065 \\
F(4 ; 191)=4,39(0,002)\end{array}$} & \multicolumn{2}{|c|}{$\begin{array}{l}0,71 \\
0,67 \\
F(17 ; 117)=16,79(0,000)\end{array}$} & \multicolumn{2}{|c|}{$\begin{array}{l}0,74 \\
0,69 \\
F(21 ; 113)=15,199(0,000) \\
\text { F-tests of linear restric- } \\
\text { tions for objective factors: } \\
\mathrm{F}(4 ; 113)=3,26(0,014) \\
\text { For subjective factors: } \\
\mathrm{F}(17 ; 113)=16,77(0,000)\end{array}$} \\
\hline
\end{tabular}

* significance of $10 \%, * *$ significance of $5 \%, * * *$ significance of $1 \%$

Source: author's own research

\section{DISCUSSION AND CONCLUSIONS}

On the basis of the hypotheses verification it is possible to conclude that risk perception depends on both objective and subjective factors. As for the former ones, one can assert that the higher the monthly income from farming operations, the higher the drought risk perception. It is also higher when the farm specialises in plant output, when beet roots are cultivated (high-cost cultivation) or triticale and when the income from farming is a larger share in farm's general income. 
One may conclude then that the higher the exposure and vulnerability to risk, the higher the drought risk perception, which is in accordance with previous expectations.

As far as subjective factors are concerned, one can notice that the higher the average reduction in yield or income of the farm caused by previous year's drought the higher the risk perception. However, perception is not affected by the frequency of these occurrences. Therefore, it turns out that severe loss, even though less frequent, have a greater influence on drought risk perception than smaller loss even if it is more frequent, which may be due to the fact that farmers tend to accept fluctuations in yields of up to $10 \%$. Nevertheless, one can state that farmers apply availability heuristic. Drought risk perception is also affected by frequency of certain other experiences resulting from drought, i.e. fires, difficulties in obtaining loans, lowering the family's standard of living or conflicts; surprisingly, greater frequency of these experiences lowers drought risk perception.

Among the factors analysed on the basis of psychometric paradigm, the degree of conviction that drought is a threat to the farm's survival became relevant - the higher it is, the higher the drought risk perception. Next, a strong conviction that the impact of drought is a postponed one and that it is well-known to science lowers the drought risk perception. This is caused by the fact that a larger temporal distance causes both positive and negative effects to be underestimated (hence the urge of entities to postpone negative effects and to possibly accelerate achievement of benefits) [49]. Moreover, a broader knowledge of risk contributes to its more accurate assessment and to taking more suitable action in the case of adverse effects [50]. It can be rather surprising that respondents tend to perceive drought risk as increasingly lower when the number of affected farms rises in their opinion. Most probably this is connected with the fact that in the years when drought was extensive in scope, a whole array of aid forms was provided from the state budget. Farmers perceive drought risk by reducing its attributes to four dimensions, namely catastrophic potential, immediacy of effect, the degree to which the risk is known to science and the number of farms exposed to drought.

Drought risk perception is also lowered by higher level of trust in experts' opinions about the scope, causes and necessary actions to be taken with regard to drought as well as by a higher level of trust in the media informing about drought. One can presume, therefore, that in the process of drought management, like in other cases of catastrophic risk, communication is key.

Considering sociodemographic factors, in the light of the conducted study, essential influence on risk perception comes from age and education level, in both cases acting as stimulant.

The model based on objective factors offers very little explanation as for risk perception volatility. On the other hand, the model taking into consideration only subjective factors explains the volatility of endogenous variable in $71 \%$. The model regarding all the relevant objective and subjective variables in models 1 and 2 explains volatility in 74\%. This corroborates the assumption that subjective factors explain risk perception to a much greater degree than objective factors. Considering standardised Beta coefficients in each model (not presented in the table) one can assert that in model the endogenous variable is largely affected by the farms plant specialisation. Other exogenous variables show convergent absolute values of Beta coefficients. In the group of subjective factors in model 2 risk perception is affected to the largest extent by the frequency of difficulties in obtaining loans, frequency of reduction in investments caused by drought, frequency of threat to the farms' survival, average level of loss in farm's income and its frequency of occurrence. These factors also affected to the largest extent the changes in the endogenous variable in model 3 along with age category of 31-35 and 46-50 years of age, In this 
way, one may presume that perceptions depend mainly on experiences and sociodemographic traits (age), while trust in the state's ability to control risk is of slightly smaller importance.

Summing up the conducted analysis, it is possible to assert that although a correlation between objective variables and the level of risk perception has been identified, it is vital that exposure and vulnerability to drought risk provide very little explanation for drought risk perception variance. On the other hand, subjective factors offer explanation in over seventy percent. This means that heterogeneity of drought risk perception is not caused by differences in exposure or vulnerability to risk; on the contrary, it is mainly due to individual factors. At the same time, it becomes clear why the same objective risk may generate its versatile perceptions.

Because the correlation between risk perception and mitigation behavior is ambiguous $[9,12,30,33,51-56]$ the above considerations should be extended towards analysis of linkages between cognitive perception of risk by farmers and their taking action aimed at risk control, such as purchasing insurance. It would enable, among other things, a realistic construction of plans aimed at preventing the impact of drought, at least in the part which requires farmers' activity.

\section{ACKNOWLEDGEMENT}

The work was funded by the National Science Centre based on the decision number DEC2018/02/X/HS4/02781

\section{REFERENCES}

[1] Elbehri, A., Challinor, A., Verchot, L., Angelsen, A., Hess, T., Ouled Belgacem, A., Clark, H., Badraoui, M., Cowie, A., Silva, S. De, Erickson, J. Joar Hegland, S., Iglesias, A., Inouye, D., Jarvis, A., Mansur, E., Mirzabaev, A., Montanarella, L., Murdiyarso, D., Notenbaert, A., Obersteiner, M., Paustian, K., Pennock, D., Reisinger, A., Soto, D., Soussana, J.-F., Thomas, R., Vargas, R., Wijk, M. Van and Walker, R. (2017) FAO-IPCC Expert Meeting on Climate Change, Land Use and Food Security: Final Meeting Report; January 23-25, 2017 FAO HQ Rome. http://www.ipcc.ch/pdf/supporting-material/EM_FAO_ IPCC_report.pdf. Accessed November 2, 2017.

[2] Iglesias, A. and Garrote, L. (2015) Agricultural Water Management Adaptation strategies for agricultural water management under climate change in Europe. Agricultural Water Management 155, 113-124. https://ac.els-cdn.com/S037837741500089X/1-s2.0S037837741500089X-main.pdf?_tid=ece4c9f8-c2e7-11e7-a16c-00000aab0f6b\&acdnat $=1509968883 \_$b75abfa935106666eef0d5fada08d723. Accessed November 6, 2017.

[3] European Commission (2012) Communication from the Commission to the European Parliament, the Council, the European Economic and Social Committee and the Committee of the Regions. Report on the Review of the European Water Scarcity and Droughts Policy. http://eur-lex.europa.eu/legal-content/EN/TXT/PDF/?uri=CELEX:52012DC0672\&from=EN. Accessed November 2, 2017.

[4] JRC (2017) Severe drought in Italy - July 2017. http://edo.jrc.ec.europa.eu/documents/news/ EDODroughtNews201707_Italy.pdf.

[5] Explaining the lack of rain in Spain (and Italy) (2017). The Economist. https://www.economist.com/europe/2017/08/10/explaining-the-lack-of-rain-in-spain-and-italy.

[6] JRC (2018) Drought in Central-Northern Europe - July 2018. http://edo.jrc.ec.europa.eu/ documents/news/EDODroughtNews201807_Central_North_Europe.pdf. 
[7] OECD (2016) Mitigating Droughts and Floods in Agriculture. Policy Lessons and approaches., OECD Publishing, Paris.

[8] Ogurtsov, V. a., Asseldonk, M. a P.M. Van and Huirne, R.B.M. (2009) Purchase of catastrophe insurance by Dutch dairy and arable farmers. Review of Agricultural Economics 31, 143-162.

[9] Sherrick, B.J., Barry, P.J., Ellinger, P.N. and Schnitkey, G.D. (2004) Factors Influencing Farmers' crop Insurance Decisions. American Journal of Agricultural Economics 86, 103114.

[10] Dobbie, M.F. and Brown, R.R. (2014) A framework for understanding risk perception, explored from the perspective of the water practitioner. Risk Analysis 34, 294-308.

[11] Harwood, J., Heifner, R., Coble, K., Perry, J. and Somwaru, A. (1999) Managing Risk in Farming: Concepts, Research, and Analysis. Agricultural Economic Report 774, 1-83.

[12] Tucker, C.M., Eakin, H. and Castellanos, E.J. (2010) Perceptions of risk and adaptation: Coffee producers, market shocks, and extreme weather in Central America and Mexico. Global Environmental Change 20, 23-32.

[13] Duinen, R. van, Filatova, T., Geurts, P. and Veen, A. van der (2015) Empirical Analysis of Farmers' Drought Risk Perception: Objective Factors, Personal Circumstances, and Social Influence. Risk Analysis 35, 741-755.

[14] Urquijo, J. and Stefano, L. De (2016) Perception of drought and local responses by farmers: A perspective from the Jucar river Basin, Spain. Water Resources Management 30, 577-591.

[15] Bryan, K., Ward, S., Barr, S. and Butler, D. (2019) Coping with Drought: Perceptions, Intentions and Decision-Stages of South West England Households. Water Resources Management 33, 1185-1202.

[16] Giordano, R. and Vurro, M. (2010) Fuzzy Cognitive Map to Support Conflict Analysis in Drought Management. In: Fuzzy Cognitive Maps. Studies in Fuzziness and Soft Computing, Ed: M. Glykas, Springer, Berlin, Heidelberg. pp 403-425.

[17] Blanka, V., Ladányi, Z., Szilassi, P., Sipos, G., Rácz, A. and Szatmári, J. (2017) Public Perception on Hydro-Climatic Extremes and Water Management Related to Environmental Exposure, SE Hungary. Water Resources Management 31, 1619-1634.

[18] Boholm, А. (2003) The cultural nature of risk: Can there be an anthropology of uncertainty? Ethnos 68, 159-178.

[19] Central Statistical Office (2018) Statistical Yearbook of Agriculture, Warsaw.

[20] Aven, T. and Renn, O. (2010) Risk Management and Governance. Concept, Guidelines and Applications, Springer-Verlag, Berlin, Heidelberg.

[21] Collins, R., Kristensen, P. and Thyssen, N. (2009) Water Resources Across Europe Confronting Water Scarcity and Drought.

[22] Lanen, H. a J. Van, Alderlieste, M. a, Acacio, V., Garnier, E., Gudmundsson, L., Monteagudo, D.H., Lekkas, D., Paredes, J., Solera, A., Assimacopoulos, D., Rego, F., Seneviratne, S., Stahl, K. and Tallaksen, L.M. (2013) Quantitative analysis of historic droughts in selected European case study areas.

[23] Łabędzki, L. (2017) Parameterization of Drought Vulnerability in Agriculture. Infrastructure and Ecology of Rural Areas II, 535-544.

[24] Rocha, M.S. and Lanen, H.A.J. Van (2015) Links Between Meteorological Drought Indices and Yields (1979 - 2009) of the Main European Crops.

[25] Łabędzki, L. and Bąk, B. (2015) Indicator-based monitoring and forecasting water deficit and surplus in agriculture in Poland. Annals of Warsaw University of Life Sciences - SGGW. Land Reclamation 47, 355-369. https://content.sciendo.com/view/journals/ sggw/47/4/article-p355.xml. 
[26] Kaczała, M. (2017) Perception of risk by farmers and crop insurance decisions -Polish case. In: 21st APRIA 2017 Annual Conference; 30th July to 2nd August 2017. http://apria2017. syskonf.pl/conf-data/APRIA2017/files/Paper Kaczala_APRIA_2017.pdf.

[27] Kahneman, D. and Tversky, A. (1979) Prospect Theory: An Analysis of Decision under Risk. Econometrica 47, 263-292. http://links.jstor.org/sici?sici=00129682\%28197903\%2947\%3A2\%3C263\%3APTAAOD\%3E2.0.CO\%3B2-3. Accessed July 30, 2017.

[28] Tversky, A. and Kahneman, D. (1986) Rational Choice and the Framing of Decisions. The Journal of Business 59, 251-278.

[29] Kahneman, D. and Tversky, A. (1973) On the Psychology of Prediction. Psychological Review 80, 237-251.

[30] Kaczała, M. and Wiśniewska, D. (2015) Polish farmers' perception of spring frost and the use of crop insurance against this phenomenon in Poland. Economic and Business Review 15, 90-111.

[31] Astfj, D. V, Peters, E. and Slovic, P. (2014) Cognition and Neurosciences The affect heuristic, mortality salience, and risk: Domain-specific effects of a natural disaster on risk-benefit perception. 527-532.

[32] Keller, C., Siegrist, M. and Gutscher, H. (2006) The role of the affect and availability heuristics in risk communication. Risk Analysis 26, 631-639.

[33] Wachinger, G., Renn, O., Begg, C. and Kuhlicke, C. (2013) The risk perception paradox-implications for governance and communication of natural hazards. Risk Analysis 33, 1049-1065.

[34] Paul Slovic (1987) Perception of Risk. Science 236, 280-285. http://socsci2.ucsd.edu/ aronatas/project/academic/risk slovic.pdf.

[35] Slovic, P., Fischhoff, B. and Lichtenstein, S. (1985) Characterizing perceived risk. https:// papers.ssrn.com/sol3/papers.cfm?abstract_id=2185557. Accessed July 7, 2017.

[36] Slovic, P., Fischhoff, B. and Lichtenstein, S. (1985) Characterizing perceived risk. In: Perilous progress: Managing the Hazards of Technology, Eds: R.W. Kates, C. Hohenemser and J.X. Kasperson, Westview. pp 91-123.

[37] Slovic, P., Fischhoff, B. and Lichtenstein, S. (1984) Behavioral decision theory perspectives on risk and safety. Acta Psychologica 56, 183-203. https://www.researchgate.net/ profile/Baruch_Fischhoff/publication/256105116_Behavioral_Decision_Theory_Perspectives_on_Risk_and_Safety/links/5619390a08ae78721f9cfed1/Behavioral-Decision-Theory-Perspectives-on-Risk-and-Safety.pdf. Accessed July 30, 2017.

[38] Fischhoff, B., Slovic, P., Lichtenstein, S., Read, S. and Combs, B. (1978) How safe is safe enough? A psychometric study of attitudes towards technological risks and benefits. Policy Sciences 9, 127-152.

[39] Englander, T., Farago, K., Slovic, P. and Fischhoff, B. (1986) A comparative analysis of risk perception in Hungary and the United States. Social Behaviour 1, 55-66.

[40] Teigen, K.H., Brun, W. and Slovic, P. (1988) Societal risks as seen by a Norwegian public. Journal of Behavioral Decision Making 1, 111-130.

[41] Kleinhesselink, R.R. and Rosa, E.A. (1991) Cognitive Representation of Risk Perceptions: A Comparison of Japan and the United States. Journal of Cross-Cultural Psychology 22, $11-28$.

[42] Karpowicz-Lazreg, C. and Mullet, E. (1993) Societal Risk as Seen by the French Public. Risk Analysis 13, 253-258.

[43] Goszczyńska, M., Tyszka, T. and Slovic, P. (1991) Risk perception in Poland: A comparison with three other countries. Journal of Behavioral Decision Making 4, 179-193. 
[44] Kasperson, R.E., Renn, O., Slovic, P., Brown, H.S., Emel, J., Goble, R., Kasperson, J.X. and Ratick, S. (1988) The social amplification of risk: A conceptual framework. Risk Analysis 8, 177-187.

[45] Kellens, W., Terpstra, T., Schelfaut, K. and Maeyer, P. De (2013) Perception and Communication of Flood Risks: a systematic review of empirical research. Risk Analysis 33, 2449. https://biblio.ugent.be/publication/3163311/file/6787664.pdf. Accessed July 28, 2017.

[46] Ullah, R., Shivakoti, G.P. and Ali, G. (2015) Factors effecting farmers' risk attitude and risk perceptions: The case of Khyber Pakhtunkhwa, Pakistan. International Journal of Disaster Risk Reduction 13, 151-157. http:/ac.els-cdn.com/S2212420915300121/1-s2.0S2212420915300121-main.pdf?_tid=1dec0962-45e8-11e7-a894-00000aacb35d\&acdnat $=1496225069 \_a 4 b d b 1 f 6 c 4366 f 71611 b 0 c b 57 e 30 a d 37$. Accessed May 31, 2017.

[47] Ullah, R., Shivakoti, G.P., Zulfiqar, F., Iqbal, M.N. and Shah, A.A. (2017) Disaster risk management in agriculture: tragedies of the smallholders. Natural Hazards 87, 1361-1375.

[48] Botzen, W.J.W., Aerts, J.C.J.H. and Bergh, J.C.J.M. Van Den (2009) Dependence of flood risk perceptions on socioeconomic and objective risk factors. Water Resources Research 45, 1-15.

[49] Kozielecki, J. (1977) Psychologiczna teoria decyzji, drugie por., Państwowe Wydawnictwo Naukowe, Warszawa.

[50] Goszczyńska, M. (1997) Człowiek wobec zagrożeń, Wydawnictwo 'Zak', Warszawa.

[51] Ullah, R., Shivakoti, G.P., Kamran, A. and Zulfiqar, F. (2016) Farmers versus nature: managing disaster risks at farm level. Natural Hazards 82, 1931-1945.

[52] Liu, F., Corcoran, C.P., Tao, J. and Cheng, J. (2016) Risk perception, insurance recognition and agricultural insurance behavior-An empirical based on dynamic panel data in 31 provinces of China. International Journal of Disaster Risk Reduction 20, 19-25. http://www.sciencedirect.com.000042cv025a.han3.ue.poznan.pl/science/article/pii/ S2212420916301352. Accessed April 5, 2017.

[53] Birkholz, S., Muro, M., Jeffrey, P. and Smith, H.M. (2014) Rethinking the relationship between flood risk perception and flood management. Science of The Total Environment 478, 12-20. http://www.sciencedirect.com.00004272012c.han3.ue.poznan.pl/science/article/pii/ S0048969714000709. Accessed May 10, 2017.

[54] Woods, B.A., Nielsen, H.Ø., Pedersen, A.B. and Kristofersson, D. (2017) Farmers' perceptions of climate change and their likely responses in Danish agriculture. Land Use Policy $\mathbf{6 5}$, 109-120. http://ac.els-cdn.com.00004272014f.han3.ue.poznan.pl/S0264837717303812/1s2.0-S0264837717303812-main.pdf?_tid=70b6ca42-3576-11e7-aecf-00000aacb35d\&acdnat $=1494417027$ f5c92824ef98b14a266ea294c11f8347. Accessed May 10, 2017.

[55] Grothmann, T. and Patt, A. (2005) Adaptive capacity and human cognition: The process of individual adaptation to climate change. Global Environmental Change 15, 199-213. https:// www.pik-potsdam.de/news/public-events/archiv/alter-net/former-ss/2009/14.09.2009/ schroeter/literature/grothmann_patt.pdf. Accessed July 28, 2017.

[56] Wheeler, S., Zuo, A. and Bjornlund, H. (2013) Farmers' climate change beliefs and adaptation strategies for a water scarce future in Australia. Global Environmental Change 23, 537-547. http://www.elsevier.com/authorsrights. Accessed July 30, 2017. 